\title{
A CASE STUDY ON BOTANICAL PESTICIDES AND VERMICOMPOST FERTILIZER FOR ADOPTING NEW AGRICULTURAL PRACTICE BY FARMERS
}

\author{
Manoj Kaphle ${ }^{1}$ Nagendra Bastakoti ${ }^{2}$
}

\begin{abstract}
For last 3 years, vegetable growers from Devdaha and Kerawani VDC of Rupandehi and Daunnedevi and Rupaulia VDC of Nawalparasi districts Nepal are concerned to minimize the practices of using chemical pesticides exploring several options. Action research was carried out to dessiminate the effect of botanical pesticide and vermi-compost fertilizer with major aspects: perception and adaptation. Household surveys and focus group discussions (FGDs) were carried out which was analyzed measuring frequency; percentage; indexing; mean and standard deviation. Results show that the adoption rate of botanical-pesticides and vermicompost was increased by $45 \%$ and $60 \%$ respectively. More than $80 \%$ farmers were motivated towards the use of vermi-compost and botanical pesticides. Vermi-compost was also found cost efficient comparing with Urea. More could have been done in transforming conventional farming into an organic one in studied area, where commercial olericulture has been seen as a booming business.
\end{abstract}

Key words: Botanical pesticide, Perception of farmers, Raw materials and Vermicompost

\section{INTRODUCTION}

Rupandehi and Nawalparasi districts lie in western Terai parts in the western development region of Nepal covering 1360 and 2162 Sq. Km, respectively (DADO, 2014). Research area covers four Village Development Committees (VDCs), two in each district: Kerwani and Devdaha VDCs lie in Rupandehi district whereas Daunnedevi and Rupaulia VDCs in Nawalparasi district. A small survey before research provided scenario of people and their livelihoods in these four VDCs. Regarding the survey, education level of people was categorized into five levels, namely- Illiterate, literate (non-formal education), education level between class one to class five, class six to secondary level and above. Among them, only three levels were observed and majority of farmers found to be in between class 6 to secondary level. $17 \%$ farmers were illiterate and that of $30 \%$ were observed with education levels of class 1 to 5 . In the other hand, land was found as main asset of people which determined their economic status in these VDCs. $47 \%$ house hold found with less than 0.5 hectare of land, $33 \%$ $\mathrm{HH}$ with 0.5 ha to 1 ha of land and reaming $20 \% \mathrm{HHs}$ owned more than one ha of land. Same as about $80 \%$ farmers appeared with one hectare or less than that. The average land holding found 0.62 ha $( \pm 0.576)$. Same as livestock unit also considered as property of marginal people, larger the number, higher the status in society. 95\% farmers were holding at least one cow or buffalo and/or few goats to feed their family as well as sell the product if found surplus. The average number of livestock per $\mathrm{HH}$ was $3.46( \pm 1.81)$ livestock unit $(\mathrm{LU})$. The minimum and maximum numbers of livestock found to be 1 and 8.8 units, respectively (UMN, 2014).

Growing vegetables for their consumption was found as good practice initiated from last 6 years, however few people initiated $(20 \mathrm{HH})$ vegetable as their business. $100 \mathrm{HH}$ found growing vegetable to sell in market. Khaireni in Rupandehi and Bardaghat in Nawalparasi was the local market hub for this product. Only $5 \%$ growers were able sell their product in big markets, Butwal and Parasi Bazzar, where they got more profit than other. Use of chemical pesticide by the commercial

\footnotetext{
${ }^{1}$ Credit Officer at Agricultural Development Bank ; Email: manokafz@gmail.com; Contact number: (977) 9851161790

2. Programme Manager at United Mission to NepalEmail: nagendra_bastakoti@yahoo.com Contact Number : (977) 9855063408
} 
growers was common in the beginning days which was further controlled with introduction of alternative means such as urine, dung, herbs and plant debris (UMN 2013).

As several studies concluded that misuse of pesticides has caused soil degradation especially in the area of commercial agricultural production, it is essential to reduce the impact of chemical on both human and soil health by using alternatives means to control insect and pest in Nepal. Majority of the farmers are unaware of pesticide types, level of poisoning, safety precautions and potential hazards on health and environment. According to the latest estimate, the annual import of pesticides in Nepal is about $211 \mathrm{mt}$. a.i. with 29.19\% insecticides, 61.38\% fungicides, $7.43 \%$ herbicides and $2 \%$ others. The gross sale value accounts US $\$ 3.05$ million per year. Average pesticides use in Nepal is $142 \mathrm{~g}$ a.i./ha, which is very low as compared to other Asian counties (Sharma et al 2012). Pesticidal misuse is a serious concern. Over use of these chemicals have severe effects on environment that may lead to an immediate and long term effects. Investigating farmers' awareness of agrochemicals residues and their behaviors regarding application is important in order to reduce human factors that negatively affect agricultural safety (Bhandari, 2014).

In this regard, various organizations are concerned to minimize the practices of using chemical pesticides by exploring several options while performing the interventions through different types of programme. Home gardeners in Nepal apply Zhol Mol, an organic liquid pesticide made of Neem leaves, Timur, garlic, livestock urine, and water, to their vegetables and fruits. Similarly, farmers in Nepal also found using Neem trees as a natural pesticide. Neem trees, which can also be found in the Sahara Desert and Florida, can repel pests such as spider mites and cutworms (Salinger, 2012). Similarly creating awareness through training, campaign, visit to organic farm and demonstration on organic pesticides (made from plant and animal debris) are major ways applied to minimize the effect of chemical pesticides in recent days. In addition, knowledge has been transferred on preparation of compost and vermi-compost in farmer's field of ten districts of Nepal including Nawalparasi and Rupandehi, which also minimized the practice of using chemical fertilizers beyond the recommended dose. Hence, the study was carried out to document the "Effect of botanical pesticide (BP) and vermi-compost (VC) fertilizer on three major aspects: perception and adaptation by the vegetable growers living in Rupandehi and Nawalparasi districts, where farmers started to adopt alternative means of pesticide and chemical fertilizer while cultivating vegetables.

\section{METHODOLOGY}

The methodology consists of conceptual framework, operational definition, location of the study, sampling techniques, procedure and sample size, research instruments, level of data collection and data analysis.

\section{AREA OF ACTION RESEARCH}

This study was conducted in Kerwani and Devdaha VDCs of Rupandehi district (1360 sq.km) and Daunnedevi and Rupaulia VDCs of Nawalparasi district (2162 sq.km). Both districts lie in western Terai parts in the western development region of Nepal (DADO Rupandehi, 2013 and DADO Nawalparasi, 2013).

SAMPLING TECHNIQUE, PROCEDURE AND SAMPLE SIZE

Farmer practicing at least one activity either vermi-compost and/or BP preparation of respective VDCs constituted the sampling population of this study. It has already been found from the preliminary key informant survey that the numbers of vermi-compost users and botanical pesticide 
users in VDCs were $100 \mathrm{HHs}$ but only the sample of $30 \mathrm{HHs}$ were selected for individual interview along with four focal group discussion having 20 members in each discussion.

TECHNIQUES OF DATA COLLECTION

Face to face interview method was used to collect the information. The respondents were interviewed with the help of semi-structured questionnaire. Focus Group Discussions were also carried out to collect primary data.

DATA ANALYSIS

A number of descriptive and inferential statistical tools were employed to analyze the data such as frequency; percentage; indexing; mean and standard deviation etc. The statistical method used for inferential purpose was correlation coefficient $(r)$. These were tested at 0.01 and 0.05 level of significance. Pearson Product moment correlation coefficient ' $r$ ' was used to predict the interdependencies of the independent variables.

\section{RESULT AND DISCUSSION}

CROP YIELD

On an average, one farmer was producing vegetables from 1332 to 1665 meter square of land. However, about 40\% farmers found lacking to supply sufficient amount of FYM in their land. More than $65 \%$ farmers claimed that they are succeeding in reducing use of chemical pesticides in vegetables significantly (25\%). According to them, all of them are using both chemical and organic means of inputs and only practices are not sufficient at the moment and it will not be sustainable. During FGD farmers could not deny that yield of organically produced either vegetables or crops in the first two years will decreased but it can be gradually recovered after 3 years. During this period small farmers cannot sustain because of investment and profits.

Majority of farmer assumed that yield would be decreased for the first and second year and they believe on the production increment after 3rd year, however, financial difficulties occurred to sustain the practice. So they were extremely reluctant to adopt complete organic crops and vegetable production. It is obvious that farmer may incur loss in two ways: firstly by losing productivity and secondly by investing higher cost of production. So, it would be difficult to sustain for small holders as majority of the farmers are holding less than 0.5 ha of land. It was revealed that yield of vegetable in the observed $\mathrm{HH}$ was not consistent. Some farmers claimed the decrease in the production of potato and cauliflower whereas some of them reported increase by 10-20 percent.

Overall, there still is maneuver to see the effect of vermi-compost and botanical pesticide on yield of crops. Yield recorded during research could not justify the consistence of yield; increase or decrease in yield might be due to vermin-compost and BPs or might not. For this in-depth analysis from larger area is required.

\section{DIMINISHING USE OF CHEMICAL PESTICIDES AND FERTILIZERS}

The survey identified that $45 \%$ of the respondents following botanical pesticide and $60 \%$ respondents adopting vermi-compost which was disappeared or not known before three years. In the mean time, the respondents showed their unhappiness with some specific pest and diseases (during FGD) hence, some of them had been using chemical pesticides as well. According to them, chemical fungicides required to control late blight of potato and tomato and that of soil dwelling insects like white grub, cutworms. Farmers could not find any registered organic pesticides to control these disease 
and pests. So, sometime they used Copper Sulphate to control some diseases in tomato which was too expensive to use in tomato.

The study identified that farmer's awareness about the hazard category of pesticides. So they reduced the application of chemical pesticides especially those which are extremely hazardous pesticides i.e. red category of insecticides (phorate (thimet), Methyl Parathion (Malathion) and Carbofuran (Furadan), however dichlorovous is being used by farmers. Similarly, chemical fertilizers, especially rampant use of urea, had been reduced by more than $75 \%$. Its use has been reduced in vegetables and that of FYM application found increasing. According to vegetable growers use of chemical pesticides had been reduced by more than $60 \%$ and that of chemical fertilizer by more than $50 \%$. On the other hand, use of FYM and vermi-compost was found increasing. More than $80 \%$ respondents showed their interest to produce and adopt vermi-compost, however, the raw materials like FYM could not be found easily in the villages, as a result, producing vermi-compost using different raw materials started to increase. It is due to decrease in density of livestock unit in the surveyed area. Tularam Pandey, a leading farmer said that previously about $34 \mathrm{~kg}$ of chemical fertilizer was used in 333 meter square of land. They were hardly using $300 \mathrm{~kg}$ of FYM in 333 meter square of land, which started to shift by more than $600 \mathrm{~kg}$ of FYM and less than $10 \mathrm{~kg}$ of chemical fertilizer in same piece of land (333 meter square)

\section{COST OF VERMICOMPOST PRODUCTION}

All variable cost and fixed cost were taken for the cost calculation. It was observed that average cost of one kg vermi-compost was found to be Rs. 13.3. Of the total cost casual labor cost was high which accounted about $36.6 \%$ of total cost followed by earthworm cost $(21.6 \%)$, other raw materials (16\%), FYM (11.8\%) and annuity for fixed cost (14\%). Farmers were using different materials to prepare vemi-compost and botanical pesticide. Commonly; they were using sand as base, banana leaf, paper, earthworm, farm yard manure to prepare vermi-compost. The proportion of raw materials varied among the farmers. It was observed that farmers started to use raw materials especially, degradable material available locally. Similarly, in case of botanical pesticide locally available Eupatorium leaf (Eupatorium perfoliatum), Melia leaf (Melia azedarac), Neem (Azadirarchata indica), Asuro (Adhatoda vasica), Garlic, Onion, Tobacco, Chilli, urine, Sichuan pepper (Zanthoxylum Spp) Soya bean floor etc were found to be used.

Table 1.Raw material used to manufacture botanical pesticides and vermi-compost.

\begin{tabular}{|l|l|l|l|}
\hline Vermicompost & $\begin{array}{l}\text { Amount } \\
(\mathrm{kg})\end{array}$ & Botanical pesticides & Amount \\
\hline $\begin{array}{l}\text { Eupatorium leaf ( Eupatorium } \\
\text { perfoliatum) - Banmara in Nepali }\end{array}$ & 7 & Urine of cow & 7 lit \\
\hline $\begin{array}{l}\text { Malabar nut (Adhatoda vasica)- } \\
\text { Asuro in Nepali (Artemisia vulgaris)- }\end{array}$ & 20 & $\begin{array}{l}\text { Mugwort (Artemisia vulgaris)- Titepati in } \\
\text { Nepali }\end{array}$ & $3 \mathrm{~kg}$ \\
\hline $\begin{array}{l}\text { Mugwort } \\
\text { Titepati in Nepali }\end{array}$ & $\begin{array}{l}\text { Malabar nut , (Adhatoda vasica)- Asuro in } \\
\text { Nepali }\end{array}$ & $3 \mathrm{~kg}$ \\
\hline Neem leaf (Azadirarchata indica) & 5 & Neem(Azadirarchata indica) & $5 \mathrm{~kg}$ \\
\hline Melia leaf (Melia azedarac) & 5 & Chilly & $60 \mathrm{gm}$ \\
\hline Earthworm & 4 & Tobacco & $100 \mathrm{gm}$ \\
\hline & & Garlic & $100 \mathrm{gm}$ \\
\hline & $\begin{array}{l}\text { Sichuan Peeper (Zanthoxylum simulan) } \\
\text { Timur in Nepali }\end{array}$ & $50 \mathrm{gm}$ \\
\hline & \begin{tabular}{l} 
Onion \\
\hline
\end{tabular} & & $150 \mathrm{gm}$ \\
\hline
\end{tabular}


Attributes like cost, complexity, productivity, profitability, compatibility, efficiency, input available and manure sufficiency were selected and analyzed. Table 2 presented below shows the detail of attributes, while Table 3 shows their correlations. Significant contribution of compatibility to adoption behavior of farmers suggested that the preparation of vermi-compost and botanical pesticide seemed in line with the existing values, past experiences and present needs of the farmers. So, no more difficulties found to the farmers to switch-over to that practice.

Finding shows that cost of vermin-compost and botanical pesticide production is not stronger than previous parameters. So farmers ranked cost in 5th rank (Table 2), indicating other important factors to be considered. Cost is highly correlated and significant ( 0.01 level) with efficiency of vermin-compost production (Table 3). The practices which were perceived as costly by the farmers were likely to be adopted by them as much as the less costly practices. This finding was contrary to the general expectation and suggested that production cost of vermi-compost and BPs had no direct influence to its efficiency

It indicated that the practices, whether complex or simple, would be adopted equally by the farmers. It suggested that the simple and easily understood practices had faster rate of adoption than the more complex practices (Table 2).

More productive practices are always expected to be adopted by the farmers than the less productive innovations, but the present study was against this general expectation. It suggested that only production aspect could not predict the adoption behavior of farmers because more productive practices may not always be compatible.

Profitability, an important attribute of a farm practice, was found to be an important factor affecting the rate of adoption. Where farmer perceived high profits, adoption was high.

Though the finding reported no influence of efficiency on adoption of vermi-compot and botanicalpesticides, it might be partially responsible for the high correlation between compatibility and adoption as an efficient practice is always expected to have high level of adoption. (Table 2)

Table 2. Perceived attributes of vermi-compost use and botanical-pesticide use

\begin{tabular}{|l|r|r|r|}
\hline & Mean & Std. Deviation & $\mathrm{N}$ \\
\hline Parameters & 2.5667 & 0.97143 & 30 \\
Complexity & 3.0667 & 0.98027 & 30 \\
Input availability & 3.3333 & 1.21296 & 30 \\
compatibility & 3.6000 & 1.22051 & 30 \\
Cost & 3.7667 & 1.30472 & 30 \\
Productivity & 3.9667 & 0.55605 & 30 \\
Efficiency & 4.0333 & 0.96431 & 30 \\
Profitability & 4.3000 & 0.74971 & 30 \\
\hline
\end{tabular}


Table 3. Correlation on perceived attributes of vermi-compost use and botanical-pesticide use

\begin{tabular}{|c|c|c|c|c|c|c|c|c|}
\hline & Cost & Complexity & productivity & Profitability & compatibility & efficiency & Inputavailable & Manure \\
\hline Cost & 1 & & & & & & & \\
\hline Complexity & $0.417^{*}$ & 1 & & & & & & \\
\hline productivity & -0.059 & 0.067 & 1 & & & & & \\
\hline Profitability & 0.004 & -0.075 & $0.687^{* *}$ & 1 & & & & \\
\hline Compatibility & 0.069 & $0.398^{*}$ & $0.640^{* *}$ & $0.701^{\text {** }}$ & 1 & & & \\
\hline Efficiency & $0.527^{* *}$ & $0.472^{* *}$ & 0.259 & $0.415^{*}$ & $0.627^{* *}$ & 1 & & \\
\hline Inputavailable & 0.225 & 0.010 & $0.682^{* *}$ & $0.720^{* *}$ & $0.489^{* *}$ & 0.344 & 1 & \\
\hline ManureSufficiency & $0.380^{*}$ & 0.285 & $0.547^{* *}$ & $0.658^{* *}$ & $0.692^{* *}$ & $0.679^{* *}$ & $0.712^{* *}$ & \\
\hline
\end{tabular}

Input availability was ranked in fifth most important factor of adoption by farmers. For vermicompost preparation and botanical-pesticide preparation input are not major problem in the adoption of those techniques. Manure availability was also asked to rank, but this was the last important factor of adoption as this is easily available in the villages, which also corroborates by the number of livestock holding by individual households.

\section{ACCEPTABILITY OF BOTANICAL PESTICIDE AND VERMICOMPOST FERTILIZER}

It was revealed that more than $70 \%$ of the farmers claimed to produce vermi-compost without further training, however, were looking for more technical help in different aspects like introducing novel ideas in villages. So, regarding reason of its adoptability farmers were asked to rank different parameters. The perceived reasons for the production of vermin-compost and botanical-pesticides are given in the Table 3. It was observed that healthy or no side effect from vegetables produced by using vermin-compost and botanical-pesticide ranked first position followed by maintenance of soil fertility and tasty and nutritious, Same as conservation of environment, longer storability and lower economic burden ranked 4th and 5th position, meanwhile, efficient use of local resources and high preferences by the consumers came at 6th and 7th positions respectively. Vegetables produced by using either vermi-compost and/or botanical-pesticides found to be used in household level for daily consumption but not for the market. They believed that vegetables produced without chemical means have no side effect on human health. However, market for those products not secured due to same market price between chemical used and chemical free products in market. They claimed that the use of organic manures in terms of vermi-compost and use of botanicalpesticides might increas the activities of microorganisms as an result they felt increasing status of soil fertility.

Table 3. Preference given to Botanical pesticide and Vermi-compost to produce vegetable

\begin{tabular}{|l|c|c|}
\hline \multicolumn{1}{|c|}{ Reasons } & Index & Rank \\
\hline Maintenance of soil fertility & 0.49 & 2 \\
\hline Vegetables- tasty and nutritious & 0.52 & 3 \\
\hline Conservation of environment & 0.53 & 4 \\
\hline Longer storage life & 0.60 & 5 \\
\hline Lower economic burden & 0.60 & 5 \\
\hline Efficient use of local resources & 0.63 & 7 \\
\hline High preference by consumers & 0.65 & 7 \\
\hline
\end{tabular}


The above results show the high level of awareness on the farmers for the conservation of environment. In their own words, they started to reduce the use of chemical fertilizers and pesticides as they became familiar with hazardous effect of those chemical means. The chemical fertilizer and pesticides used in the fields get washed out of the soil into the source of water contaminating the drinking water. Further, the chemical pesticides sprayed on crops and vegetables made the environment more polluted causing many harmful effects on human and other living organisms. Farmers also experienced that vegetables produced using vermin-compost and botanicalpesticides have longer storability, more than 2-3 days. In other hand farmers found greatly lacking alternatives of chemical pesticides, due to which, they were bounded to use some pesticides for specific crops like late blight of tomato and potato.

Regarding the economic point of view, farmers thought that use of locally available resources like manure for vermicompost and like Eupatorium leaf (Eupatorium perfoliatum), Melia leaf (Melia azedarac), Neem (Azadirarchata indica), Asuro (Adhatoda vasica), Garlic, Onion, Tobacco, Chilli, urine for botanical-pesticides reduces the economic burden. However, they claimed that the voluminous production is a big challenge and side by side uniform quality of the botanical-pesticide was found to be a great problem. Farmers claimed that the consumers relatively prefer the products produced without chemical means but due to the lack of standardization of such products consumers had suspicion whether to buy or not. So, they are not ready to pay high prices in research area.

In an other hand, it was observed that the farmers faced many problems related to technical, production and consumption aspects of vermi-compost and botanical-pesticides. This study identified pest and disease attack as most serious problem in the field using vermi-compost and botanical-pesticides. Other problems, like, lack of enough knowledge on vermi-compost and botanical pesticide preparation, negligence of consumers, no price differentiation, lack of effective organic fertilizers and pesticides, lack of adequate biomass (raw materials), decrease in production, labor demanding and complexity in making procedure ranked 2nd, 3rd, 4th, 5th, 6th, 7th, 8th and 9 th, respectively. Some of the problems were found interrelated. For example, lack of proper knowledge on vermin-compost and bio-pesticides preparation, lack of adequate biomass, lack of effective organic fertilizers and pesticides, were related to more pest and disease problem and low productivity of organic vegetables. Similarly, negligence of consumers was related to not satisfactory price difference between the organic and inorganic produce (Table 4).

Table. 4 Problems faced by the adopters of organic vegetable production

\begin{tabular}{|l|c|c|}
\hline \multicolumn{1}{|c|}{ Problems } & Index value & Rank \\
\hline Complexity in making procedure & 2.55 & 8 \\
\hline More labor demanding (collection and preparation) & 1.98 & 7 \\
\hline Decrease in production & 1.95 & 6 \\
\hline Lack of adequate biomass, raw materials & 1.84 & 3 \\
\hline Negligence of consumers & 1.55 & 4 \\
\hline No price difference on product & 1.56 & 2 \\
\hline Lack of enough knowledge on preparation & 1.49 & 1 \\
\hline More pest and disease attack & 1.48 & 5 \\
\hline Lack of effective organic fertilizers and pesticides & 1.58 & \\
\hline
\end{tabular}

Most of the farmers were facing the problem of pest and disease infestation in organically produced tomato and potato. The restricted use of chemical fertilizers and pesticides, lack of effective organic fertilizers and pesticides in the market and lack of knowledge on preparation of organic pesticides increased the problem of insects and pests.

The farmers claimed that a large number of consumers are not aware of IPM or organic products. They further added that even the aware consumers never ready to pay higher price for organic produce. As stated earlier, the restricted use of chemical fertilizers, complete avoidance of synthetic pesticides, insufficiency of organic manures and botanical-pesticides, lack of effective organic fertilizers and pesticides in the market and more pest and disease problem had decreased the yield of vegetables. In addition, farmers were also facing the scarcity of laborers; however 
vermi-compost and botanical-pesticide preparation needed more laborers which ultimately increase the cost of production.

During the FGD, it was revealed that lack of time management by farmers and poor management of earthworm, seemed major practical problems. According to them, application of BPs found time consuming with high frequency of application as compare to chemical pesticide.

ORGANIC AND INORGANIC MEANS OF INPUT SOURCES

It was observed that 100 percent of farmers were adopting Integrated Pest and Nutrient. Management (IPNM) practices (about 20 to $30 \%$ were using vermi-compost and botanical pesticide as fertilizer and pesticides, respectively) in producing vegetables and crops. Researcher asked to rank the reason behind to follow integrated pest and nutrient pest management to the participant farmers. Lack of confidence was observed the prior reason which was caused due to the lack of demo plots or trial experiments locally (Table 5).

Table 5. Farmers preference on integrated farming

\begin{tabular}{|l|c|c|}
\hline \multicolumn{1}{|c|}{ Reasons } & Mean & Std. Deviation \\
\hline Lack of trials/demo-plots & 2.03 & 1.47 \\
\hline Decrease in productivity of organic vegetables & 2.06 & 0.90 \\
\hline Ineffectiveness of organic pesticides & 2.10 & 1.06 \\
\hline Lack of organic market & 2.33 & 1.18 \\
\hline Lack of enough knowledge on organic vegetable & 3.80 & 1.60 \\
\hline production & 3.86 & 1.81 \\
\hline Lack of adequate biomass & & \\
\hline
\end{tabular}

They strongly agreed to require trials and demo plots to motivate farmers towards botanical pesticide and vermin-compost which was absent in conventional farming practices in the village. Secondly, they believed that only organic production practices reduces yield of crops so they started to follow integrated pest and nutrient management practices. Ineffectiveness of organic pesticides for insects and diseases, lack of separate market channel for IPM products or organic products ranked in 3rd and 4th position, respectively. Lack of enough knowledge on vermincompost production and BP preparation for organic production found another reason of adopting integrated farming. Lack of adequate biomass or inputs for vermi-compost ranked the last; indicating that this is not the major reason for adopting integrated pest and nutrient management.

\section{FARMER'S CONCERN IN REPONSIBILITIES OF GOVERNMENT}

Farmers were also asked to rank government's role on the promotion of vermi-compost and BPs on various parameters, namely; premium price on IPM products, awareness program to producer and consumer, technical knowledge to the producers, and support on input availability and subsidy on organic inputs (Table 6).

Table 6. Farmer's perception on the role of government in promoting vermi-compost and BPs

\begin{tabular}{|l|r|r|}
\hline Options & Index & Rank \\
\hline Provide premium price on products and market assurance & 4.14 & 1 \\
\hline Awareness program to producers & 4.07 & 2 \\
\hline Aware program to consumers & 3.38 & 3 \\
\hline Provide technical knowledge to the farmers & 2.93 & 4 \\
\hline Support on input availability & 2.45 & 5 \\
\hline Provide subsidies on inputs & 2.07 & 6 \\
\hline
\end{tabular}

According to them, for the promotion and adoption of such technology government should focus primarily on premium price and market for the product. Other options like awareness program to producers, consumers, technical knowledge, input availability and subsidy on inputs kept in the orders of 2nd, 3rd, 4th, 5th and 6th respectively. Government support on providing subsidy appeared as the least important category. This reveals that farmers are more concerned about the market and premium price of the IPM/organic products. 


\section{CONCLUSION}

There are many technologies and techniques such as: Integrated Pest and Nutrient (IPNS) which is near to organic farming. Among them vermi-compost and botanical pesticides have been found easy and adoptable means of chemical free farming while comparing the people's perception and practice from last three years in Rupandehi and Nawalparasi districts. This research measured the effect of both organic means; botanical pesticide and vermi-compost on perception of farmers and its adaptation concerning to yield, cost of production and raw material availability. The result indicated farmers changing practice in vegetable farming as 100 percent of farmers started to adopt Integrated Pest and Nutrient Management (IPNM) practices which further moved towards chemical free vegetable farming system. It was found that $45 \%$ and $60 \%$, of people adopting botanical pesticide and vermi-compost respectively. About $83.3 \%$ of the farmers seemed to be motivated to the required level. In case of vermi-compost, farmers were found comparatively more motivated than that of botanical-pesticides. From the survey we can say that about $20 \%$ farmers felt high risk of losing crops if they followed only organic farming. This could be attributed to insecurities of farmers towards vermi-compost and botanical pesticides. From household survey, FGD and key informant interview we found that most of farmers were trained in different aspects of IPM or Organic farming locally followed by monitoring and supervision by District Agriculture Development Office. In the mean time, $65 \%$ farmers claimed that they became able to reduce application of chemical pesticides in vegetables significantly $(25 \%)$. The usual pretense would be risk of insect predators like red ants or lack of reinforced structures for rearing earthworm. As survey claimed, majority of farmers seemed well convinced about the effectiveness of botanical-pesticides. While calculating all variable cost and fixed cost, it was observed that average cost of one $\mathrm{kg}$ vermicompost is NRP 13.3, as compare to Urea fertilizer having NRP 25 per $\mathrm{kg}$. Hence application of vermi-compost found more cost efficient than chemical fertilizer. Regarding the yield of vegetable, majority of farmer assumed that yield would be decreased for the first and second year and they believed on the production increment after 3rd year. To address the real issues of farmers, supporting hands from government and developing organization can only bring the sustainable change in the attitude of farmers towards conservation agriculture and against conventional chemical based agriculture. Above facts and figures show that there is still a huge space to work to achieve the goal of pesticide free agricultural practice in Rupandehi and Nawalparasi districts, where people are expecting much more from concerned organization.

\section{REFERENCE}

Bhandari, G., 2014. An Overview of Agrochemicals and Their Effects on Environment in Nepal. Journal of Applied Ecology and Environment Science. Vol 2. pp 66-73.

DADO, 2013. District Agriculture Development Office, District profile, Nawalparasi, Nepal.

DADO, 2013. District Agriculture Development Office, District Profile, Rupandehi, Nepal.

Palikhe, B.R., 2002. Challenges and options of pesticide use: in the context of Nepal. Lands chaftsökologie und Umweltforschung Vol. 38. pp 130-141

Salinger G., 2012. Five ways to get rid of pest without using pesticides. Innovations that Nourish the Planet. Retrieved from http://blogs.worldwatch.org/nourishingtheplanet/five-ways-to-get-rid-of-pestswithout-using-chemicals/ on 12 January 2015

Sharma, D. R., R. B. Thapa, H. K. Manandhar, S. M. Shrestha and S. B. Pradhan, 2012. Use of pesticides in Nepal and impacts on human health and environment. The Journal of Agriculture and Environment, Vol:13, pp 67-74.

Thapa, R.B., (1997). An Overview of Pesticide Pollution in Nepal. Nepalese Horticulture, Nepal Horticulture Society, Vol.1. pp 31-39

UMN, 2014. United Mission to Nepal. Integrated Sustainable Livelihood Project. Annual report (2014-15). Thapathali Kathmandu, Nepal

UMN, 2013 . United Mission to Nepal. Integrated Sustainable Livelihood Project. Annual report (2013-14). Thapathali Kathmandu, Nepal 